\section{Acoustic Control in the Flight of Bats}

Aт the discussion following Prof. H. Hartridge's paper on "Acoustic Control in the Flight of Bats" recently read before the Linnean Society (Nature, 156, $490 ; 1945$ ), Mr. A. J. Wilmott reported that when he was a child there was in Cambridge a wellknown blind organist who was accustomed to walk about the town without the usual aids. When asked how he did it, he replied that the echoes, for example, from a brick wall, or from a low wall with railings above, appeared to him to be very different. By recognizing the different types of echo he could tell what was near him, and thus locate where he was. This acute sense of hearing even extended to the recognitionat just over two paces - of four ladies who in curiosity to see what would happen stood quite still right aeross the pavement in the organist's way. The organist hesitated a pace and then came to a complete stop. One of the ladies laughed; thereupon she was instantly recognized by the organist, who said, "I thought there was somebody there". This appears to show that sounds of ordinary frequencies have actually been used by man in much the same way as supersonic sounds are used by bats. (See also p. 692 of this issue.)

\section{Royal Asiatic Society of Bengal}

IN celebration of the bicentenary of the birth of Sir William Jones, its founder and first president, in January 1946, the Royal Asiatic Society of Bengal is arranging a Conference on Indology and Oriental Culture in the first week of January, and terminating with a banquet on the Foundation Day, January 15. Representatives of learned societies in India, China, U.S.S.R., Iran, Turkey, Great Britain and the United States, as well as individual leaders and patrons of learning, have been invited to participate in the celebrations. A booklet issued by the Society outlines the programme of special publications which has been undertaken in connexion with the bicentenary and includes the address given to the Society by Dr. L. L. Fermor on its one hundred and fiftieth anniversary in January 1934, together with Sir John Anderson's speech on the same occasion, and a list of exhibits at the conversazione. The special publications now projected include a new series of monographs to which Dr. S. K. Mitra is contributing one on the upper atmosphere; a complete author- and subject-index of all the important articles in the Asiatic Researches and the Journal and Proceedings of the Society up to the end of 1945 ; and a commemoration volume to which Dr. S. L. Hora, Dr. K. P. Brocias and Dr. K. N. Bagchi have been invited to contribute an article on the progress of scientific studies in India.

\section{Atomic Energy and its Implications}

A JoINT meeting of the American Philosophical Society and the U.S. National Academy of Sciences to discuss "Atomic Energy and its Implications" was held in Philadelphia during November 16-17. The following papers were read: Prof. H. De Wolf Smyth, "The Scientific Background of the Atomic Bomb"; Prof. J. R. Oppenheimer, "Atomic Weapons"; Prof. R. S. Stone, "The Health Protection Activities on the Plutonium Project"; Dr. J. H. Willits, "The Process of Social Adjustment to Atomic Energy"; Prof. J. Viner, "Implications of Atomic Bomb for International Relations"; Dr. Ivirng Langmuir, "World Control of Atomic Energy";
Prof. J. T. Shotwell, "The Control of Atomic Energy under the Charter". The Franklin Medal Lecture, on "Atomic Energy as a Human Asset", was delivered by Dr. Arthur H. Compton.

\section{Announcements}

DR. E. S. Russell has retired from the post of director of fishery investigations in the Ministry of Agriculture and Fisheries, but will continue to serve for some time in an advisory capacity.

MR. R. R. ENFIeLd has been appointed to a new post of chief economic adviser to the Ministry of Agriculture and Fisheries from December 4. Mr. D. A. E. Harkness, senior assistant secretary in the Ministry of Agriculture, Northern Ireland, has been appointed from the same date to succeed Mr. Enfield as principal assistant secretary in charge of the Economics and Statisties Division of the Ministry.

Prof. W. Weisbach, writing from Langeraar (Z.H.) A.95, Holland, states that he has now returned from German concentration camps, and is the sole owner of the publishing house of his partner and father-in-law, Dr. W. Junk, who died in 1942. Tabulce Biologicae, Enzymologia, Mycopathologia, etc., will be published as usual again in due course by the firm.

Dr. John R. CAMpberl, scientific officer on the staff of the Fuel Research Division of the Department of Scientific and Industrial Research, has been appointed lecturer in fuels at the Royal Technical College, Glasgow, in succession to Dr. G. S. Cruickshanks, who has retired.

The Royal Society of South Africa has elected the following as fellows: Dr. A. J. Boyazoglu, for outstanding work on agricultural problems including rural economic surveys in various lands; and Commander B. L. Goodlet, for many-sided researches in electrical engineering both in peace-time and in association with the Royal Navy.

THE following appointments, promotions and transfers in the Colonial Service have recently been made : J. D. Hunter-Smith, to be agricultural officer, Tanganyika; G. E. M. Latimer, to be veterinary officer, Nigeria ; J. P. Bernacca, to be entomologist, Uganda; E. G. N. Greaves, to be deputy Government chemist, Trinidad; Dr. E. Phillis, to be chief scientific officer, Department of Agriculture, Trinidad; D. Thornton (agricultural officer, Tanganyika), to be senior agricultural officer (soil erosion), Tanganyika; F. W. Toovey (botanist, Nigeria), to be senior botanist, Nigeria; J. A. N. Burra (assistant conservator of forests, Gold Coast), to be assistant conservator of forests, Palestine; W. J. Eggeling (senior assistant conservator of forests, Uganda), to be conservator of forests, Uganda; W. A. Fairburn (senior assistant conservator of forests, Nigeria), to be conservator of forests, Nigeria; C. B. Bissett (senior geologist, Uganda), to be deputy director of the Geological Survey, Uganda; T. Hirst (senior geologist, Gold Coast), to be deputy director of the Goological Survey, Gold Coast.

ERratum.-The British publishers of the book "Patrick Geddes" reviewed in Nature of November 24, p. 612, are the Oxford University Press, Amen House, Warwick Square, London, E.C.4, and not Messrs. Chapman and Hall, Ltd., as stated. 